\title{
USE EFFICIENCY OF NITROGEN, PHOSPHORUS AND POTASSIUM BY POTATO CULTIVARS
}

\author{
Thaísa Fernanda Oliveira ${ }^{1 *}$, Talita Gabriela Gentil ${ }^{2}$, Junia Maria Clemente ${ }^{3}$, Marcelo \\ Rodrigues dos Reis ${ }^{4}$, Leonardo Angelo de Aquino ${ }^{4}$ \\ 1 Doutoranda em Agronomia - Fitotecnia, Universidade Federal de Lavras - MG. *E-mail: \\ thaisafernanda135@gmail.com \\ ${ }^{2}$ Engenheira Agrônoma, Universidade Federal de Viçosa - Campus Rio Paranaíba - MG. \\ ${ }^{3}$ Professora contratada, Departamento de Ciência de Plantas, Faculdade do Noroeste de Minas, Paracatu - MG. \\ ${ }^{4}$ Professor adjunto, Instituto de Ciências Agrárias, Universidade Federal de Viçosa - Campus Rio Paranaíba - \\ MG.
}

\begin{abstract}
Knowledge about nutrients use efficiency in production of tubers in different potato varieties provides important basis to optimize the use of fertilizers in the crop. Thus, this study aimed to determine the productivity and the coefficient of biological utilization ( $\mathrm{kg}$ of dry matter produced per $\mathrm{kg}$ of accumulated nutrient) of nitrogen $(\mathrm{N})$, phosphorus $(\mathrm{P})$ and potassium $(\mathrm{K})$ of thirteen potato cultivars, and compare the extraction and the exportation of N, P and K of Ágata, Asterix and Atlantic cultivars that present low, medium and high content of dry matter, respectively. The treatments consisted of thirteen potato cultivars: Ágata, Atlantic, FL2215, FL2027, FL1867, FL2221, Asterix, BRSIPR Bel, Cupido, Nicolet, Accumulator, Verdi and Taurus. FL2027 cultivar was more productive. The cultivars differs as the coefficient of biological utilization of N, P and K. The Atlantic cultivar extracted and exported more N, P and K than Ágata and Asterix.
\end{abstract}

Key words: Solanum tuberosum. Extraction. Coefficient of biological utilization.

\section{EFICIÊNCIA DE UTILIZAÇÃo DE NITROGÊNIO, FÓSFORO E POTÁSSIO POR CULTIVARES DE BATATA}

RESUMO: O conhecimento da eficiência de utilização de nutrientes em produção de tubérculos de diferentes cultivares de batateira pode fornecer subsídios para otimizar o uso de fertilizantes na cultura. Assim, objetivou-se determinar a produtividade e o coeficiente de utilização biológica ( $\mathrm{kg}$ de matéria seca - MS produzida por $\mathrm{kg}$ do nutriente acumulado) de nitrogênio $(\mathrm{N})$, fósforo $(\mathrm{P})$ e potássio $(\mathrm{K})$ de treze cultivares de batata, e comparar a extração e exportação de N, P e K das cultivares Ágata, Asterix e Atlantic, de baixo, médio e alto teor de MS, respectivamente. Os tratamentos consistiram de treze cultivares de batata: Ágata, Atlantic, FL2215, FL2027, FL1867, FL2221, Asterix, BRSIPR Bel, Cupido, Nicolet, Accumulator, Verdi e Taurus. A cultivar FL2027 foi a mais produtiva. As cultivares diferem quanto aos coeficientes de utilização biológica de N, P e K. A cultivar Atlantic apresentou maior extração e exportação de N, P e K que as cultivares Ágata e Asterix.

Cultura Agronômica, Ilha Solteira, v.27, n.2, p.251-261, 2018 
Palavras-chave: Solanum tuberosum. Extração. Coeficiente de utilização biológica.

\section{INTRODUCTION}

The potato (Solanum tuberosum L.) is one of the most important foods in the world. In Brazil, the potato productivity nearly doubled in recent years, from 10 to $15 \mathrm{t} \mathrm{ha}^{-1}$ in the 1980s to 25 to $30 \mathrm{t} \mathrm{ha}^{-1}$ (FAO, 2017), with areas reaching productivities over $40 \mathrm{t} \mathrm{ha}^{-1}$.

The mineral nutrition highlights as one of the factors most important to achieve high productivities, and positive responses on potato productivity are frequently observed when nutrients are supplied in the soil (MALLMANN; LUCCHESI and DESCHAMPS, 2012; LUZ; QUEIROZ and OLIVEIRA, 2014; KAWAKAMI, 2015). The determination of nutrients extraction is primordial to calibrate the quantities that must be supplied via fertilizers (FERNANDES; SORATTO and SILVA, 2011) since the excess and the deficiency are harmful to plants growth. The excess of $\mathrm{N}$, as an example, stimulate the intense vegetative growth, reduce dry matter and starch in the tubers, delay the maturity and prolong the length of vegetative growth (CARDOSO et al., 2007).

In Brazil, technical criteria for fertilizations of potato crop needs to be updated. Frequently, the fertilizations are performed supplying fixed rates of the nutrients for several kinds of soils, cultivars, and production purposes, based only on the growers experience. Based on this context of empiricism of the fertilizations, the nutrients can be supplied in quantities over those demanded by potato crop (QUEIROZ et al., 2013).

The understanding about dry matter partitioning between the component parts of the plant, variations of this partition among cultivars and the effects of environmental conditions on the process may help in the choice of the best cultivar for each purpose and maximize tuber yield with desirable characteristics (TEKALIGN and HAMMES, 2005; CECÍLIO FILHO and PEIXOTO, 2013).

The coefficient of biological utilization express the quantity of dry matter produced per unit of nutrient accumulated in the plants. It depends on the croppings characteristic (nutrient availability, employed fertilizations, irrigation system, planting time, etc) and the plant (characteristics of the cultivars related to the capacity of nutrients absorption and the capacity to use them). In carrot croppings, the coefficient of biological utilization was different between cultivars, which brought on different accumulations of the nutrients for the same productivity in some cultivars (AQUINO et al., 2015).

Findings of differences on the nutrients use efficiency from potato cultivars may allow specific recommendations of fertilizers to the cultivars and improve the use of fertilizers in the croppings. At that, this study aimed to determine the productivity and the coefficient of biological utilization of thirteen potato cultivars, and compare the extraction and exportation of $\mathrm{N}, \mathrm{P}$ and $\mathrm{K}$ of the following cultivars: Ágata (low content of dry matter), Asterix (medium content of dry matter) and Atlantic (high content of dry matter).

Cultura Agronômica, Ilha Solteira, v.27, n.2, p.251-261, 2018 


\section{MATERIAL AND METHODS}

The experiment was performed in a field from Montesa Agropecuária Company, located in Serra do Salitre - Minas Gerais - BRA, between June and October, 2014. The soil of the fields is Latossolo Vermelho-Amarelo - very clay texture, with the following chemical attributes: $\mathrm{pH}\left(\mathrm{H}_{2} \mathrm{O}\right)=5.7, \mathrm{CEC}=65 \mathrm{mmol}_{\mathrm{c}} \mathrm{dm}^{-3}, \mathrm{P}_{\text {remaining }}=16.6 \mathrm{mg} \mathrm{L}^{-1}, \mathrm{OM}=35 \mathrm{~g} \mathrm{dm}^{-3}$, $\mathrm{P}\left(\right.$ Mehlich - 1) $=5.7 \mathrm{mg} \mathrm{dm}^{-3}, \mathrm{~K}=144 \mathrm{mg} \mathrm{dm}^{-3}, \mathrm{Ca}=23.1 \mathrm{mmol}_{\mathrm{c}} \mathrm{dm}^{-3}, \mathrm{Mg}=8.4 \mathrm{mmol}_{\mathrm{c}}$ $\mathrm{dm}^{-3}$.

The treatments consisted of thirteen potato cultivars: Ágata, Atlantic, FL2215, FL2027, FL1867, FL2221, Asterix, BRSIPR Bel, Cupido, Nicolet, Accumulator, Verdi and Taurus. The experiment was designed as randomized block with five replications. Plots presented four rows with $10 \mathrm{~m}$ length and the useful plots were the two centrals rows minus $50 \mathrm{~cm}$ in each edge. It was adopted $80 \mathrm{~cm}$ spacing between rows of plants and seed tubers (type II - mean mass of $60 \mathrm{~g}$ ) in order to reach 12 to 15 stems per $\mathrm{m}^{2}$.

Tillage was performed using two operations with harrow, one subsoiling and one rotary hoe. In the planting furrow $110,720,50,2$ and $4 \mathrm{~kg} \mathrm{ha}^{-1}$ of $\mathrm{N}, \mathrm{P}_{2} \mathrm{O}_{5}, \mathrm{~K}_{2} \mathrm{O}, \mathrm{B}$ and $\mathrm{Zn}$ were applied, respectively. As topdressing, it was applied $70 \mathrm{~kg} \mathrm{ha}^{-1}$ of $\mathrm{N}$ and $300 \mathrm{~kg} \mathrm{ha}^{-1}$ of $\mathrm{K}_{2} \mathrm{O}$. The topdressing fertilizations were splitted at 25, 40 and 50 days after planting. The hilling was performed after stem emergence (sprouting). The irrigation and phytosanitary management followed technical recommendations specific for the crop.

At 100 days after planting, the number of stems per meter of rows was counted and five stems per plot were collected. The stems were dried in an air circulation laboratory oven at $70^{\circ} \mathrm{C}$ for $72 \mathrm{~h}$. The productivity of dry matter in the shoot was estimated from the mass of stems. At harvest occasion, it was evaluated the productivity of tubers and a sample of these tubers was taken to determine the content of soluble solids and accumulated nutrients. The samples of tubers and shoot were ground in a Wiley type mill fitted with 1.27 $\mathrm{mm}$ sieve. The contents of $\mathrm{N}, \mathrm{P}$ and $\mathrm{K}$ were determined according to the method described by Malavolta, Vitti, and Oliveira (1997). The accumulations of N, P and K in each part of the plant were calculated by the product between the dry matter and the respective content of the nutrient.

The coefficient of biological utilization was calculated by the ratio between dry matter and the quantity of the nutrient accumulated in each part of the plant (tuber or shoot).

The extraction of a nutrient was the sum of the nutrient accumulation in tubers and shoot. The harvest index was calculated by the ratio between the nutrient accumulation in the tubers and the extraction of this nutrient. This index represents the percentage absorbed, which is exported as harvest.

A simulation of the extraction and exportation of $\mathrm{N}, \mathrm{P}$ and $\mathrm{K}$ in order to obtain productivities of 30, 40 and $50 \mathrm{t} \mathrm{ha}^{-1}$ was performed for Ágata (fresh market), Asterix 
(double purpose) and Atlantic (industry processing) cultivars. These cultivars contrast as regards the content of dry matter, which defines the use of each cultivar.

Ágata is used for cooking given its low content of dry matter, Asterix with medium content of dry matter can be used for cooking and industry processing while Atlantic with high content of dry matter is mainly used for industry processing (FERNANDES et al., 2010).

The extraction was calculated by the ratio between the content of the nutrients in tubers and the harvest index of this nutrient. The content of nutrients in the tubers was obtained by the ratio between the dry matter produced in tubers and coefficient of biological utilization of these nutrients for each cultivar, according to the following equations (DEZORDI et al., 2015):

$$
\begin{gathered}
\mathrm{EXT} X=\frac{100 * \operatorname{EXP} \mathrm{X}}{\mathrm{HIX}} \\
\mathrm{EXPX}=\frac{10 * \operatorname{Prod} * D M}{\operatorname{CUB~}_{t u b}}
\end{gathered}
$$

In which:

EXT X: extraction of the nutrient $\mathrm{X}\left(\mathrm{kg} \mathrm{ha}^{-1}\right)$; HI X: harvest index of the nutrient $\mathrm{X}(\%)$; EXP X: exportation of the nutrient $\mathrm{X}\left(\mathrm{kg} \mathrm{ha}^{-1}\right)$; Prod: aimed productivity of tubers $\left(\mathrm{t} \mathrm{ha}^{-1}\right)$; DM: content of dry matter of tubers $(\%)$; CBU $\mathrm{X}_{\text {tuber: }}$ coefficient of biological utilization of the nutrient $\mathrm{X}$ in the tuber $\left(\mathrm{kg} \mathrm{kg}^{-1}\right)$.

The data were submitted to variance analysis and the means of the variables of the cultivars compared by Scott-Knott test at $5 \%$.

\section{RESULTS AND DISCUSSION}

Tubers productivity was differed among cultivars (Table 1). Higher productivity was obtained for FL2027 cultivar following the Cupido and BRSIPR Bel, while the less productive were Verdi and Taurus cultivars. It was observed that, regardless the accumulation and distribution of dry matter, the more productive cultivars (FL2027, Cupido and BRSIPR Bel) were not the ones with higher quantity of dry matter in the shoot (Table 1). This result disagree with those found by Fernandez et al. (2010), in which Asterix and Mondial cultivars were the more productive, presenting maximum rates of dry matter accumulation in the shoot. These authors also observed that Ágata, Atlantic and Markies cultivars with lower accumulation rates, presented lower productivity. According to these authors, low productive potential may be related to lower photosynthetic area, because of the lower number of leaves per plant in these cultivars.

Higher productivity is associated not only with dry matter in the shoot (foliar area), but also with the capacity to translocate photoassimilates to organs of economic interest, as verified for carrot cultivars (AQUINO et al., 2015). Bregagnoli et al. (2003) emphasize that 
excessive growth of potato shoot may be a result of unbalanced fertilizations, in special excess of $\mathrm{N}$ and $\mathrm{K}$. In case of excessive leaves growth, the capture of sunlight is less efficient, which compromise the productivity of tubers.

The accumulation of dry matter and its distribution in the plant are important processes that define the crop productivity (SILVA et al., 2009). Potato tubers with high content of dry matter improve the industrial yield; beyond reduce fat absorption during frying process, resulting in a processed product with better quality (LULAI and ORR, 1979).

Atlantic cultivar is considered good for industrial processing and presented content of dry matter $(23.67 \%)$ close from previous results (PEREIRA et al., 2007). Considering the requirement of dry matter content over $20 \%$ for industrial processing (PEREIRA et al., 2007), all evaluated cultivars were able for frying, except Ágata and Cupido cultivars.

As for the total nutrients absorbed during the cycle and removed from the soil as tubers (harvest index), all cultivars reached on average $80 \%$ for N, $90 \%$ for P and $76 \%$ for $\mathrm{K}$ (Table 1). BRSIPR Bel, FL2027, FL2221, Atlantic and Taurus cultivars presented highest harvest index for N, P and K, and FL2215 and FL1867 cultivars presented the lower ones, even presenting high quantities of dry matter in the tubers when compared to other cultivars.

Fernandez et al. (2011) evaluated the exportation of macronutrients by Ágata, Asterix, Atlantic, Markies and Mondial cultivars and verified that, on average, $87 \%$ of the total $\mathrm{K}$ and $84 \%$ of the total $\mathrm{P}$ absorbed during the cycle were removed from the cropping area for the tubers, while for $\mathrm{N}$ this value was $66 \%$. They also verified that exportation of macronutrients was not directly related to the tubers productivity, as observed for Mondial cultivar, which was more productive and did not export more nutrients. Factors such as longer duration of the cycle and greater capacity of photoassimilates translocation to the tubers may increase the coefficient of biological utilization and allow greater productivity for a same nutrient accumulation. Higher fertilizers rates may increase the content of nutrients in the shoot and tubers and thereat reduce the coefficient of biological utilization for a same productivity.

There was difference among cultivars as for the coefficient of biological utilization of $\mathrm{N}, \mathrm{P}$ and $\mathrm{K}$ for the production of dry matter in the shoot, demonstrating that cultivars presented different capacity to redistribute and use these nutrients (Table 1).

Nicolet and FL2215 cultivars were less efficient for using the three nutrients (lower coefficient of biological utilization - Table 1). Lower coefficient of biological utilization in these cultivars may be due to lower employment of these nutrients in the metabolism and growth, given the higher content of these nutrients in the tissues of these cultivars, and lower values for dry matter production. The capacity to produce dry matter as function of nutrients accumulation may be influenced by physiological characteristics of the cultivar related to the net photossyntesis and the capacity of nutrient allocation in different parts of the plant (FERNANDES and SORATTO, 2013; AQUINO et al., 2015).

Cultura Agronômica, Ilha Solteira, v.27, n.2, p.251-261, 2018 
Table 1. Productivity (PROD) of potato cultivars ${ }^{1}$, dry matter of shoot (DMS) and tubers (DMTB), content of dry matter in tubers (CDMTB), harvest index of NPK and coefficient of biological utilization of NPK in the shoot (CBUS) and tubers (CBUTB).

\begin{tabular}{|c|c|c|c|c|c|c|c|c|c|c|c|c|c|}
\hline \multirow[t]{2}{*}{ Cultivars } & \multirow{2}{*}{$\begin{array}{l}\text { PROD } \\
\left(\mathrm{t} \mathrm{ha}^{-1}\right)\end{array}$} & \multirow{2}{*}{$\begin{array}{l}\text { DMS } \\
\left(\mathrm{t} \mathrm{ha}^{-1}\right)\end{array}$} & \multirow{2}{*}{$\begin{array}{l}\text { DMTB } \\
\left(\mathrm{t} \mathrm{ha}^{-1}\right)\end{array}$} & \multirow{2}{*}{$\begin{array}{c}\text { CDMTB } \\
(\%)\end{array}$} & \multicolumn{3}{|c|}{$\begin{array}{c}\text { Harvest index } \\
(\%)\end{array}$} & \multicolumn{3}{|c|}{$\begin{array}{c}\text { CBUS } \\
\left(\mathrm{kg} \mathrm{kg}^{-1}\right)\end{array}$} & \multicolumn{3}{|c|}{$\begin{array}{l}\text { CBUTB } \\
\left(\mathrm{kg} \mathrm{kg}^{-1}\right)\end{array}$} \\
\hline & & & & & $\mathrm{N}$ & $\mathrm{P}$ & $\mathrm{K}$ & $\mathrm{N}$ & $\mathrm{P}$ & $\mathrm{K}$ & $\mathrm{N}$ & $\mathrm{P}$ & $\mathrm{K}$ \\
\hline Ásterix & $4 \mathrm{c}$ & $1.11 \mathrm{c}$ & $28 \mathrm{~b}$ & $19.97 \mathrm{c}$ & $78.4 \mathrm{~b}$ & $90.1 \mathrm{a}$ & $71.7 \mathrm{~b}$ & $39.7 \mathrm{c}$ & $545.0 \mathrm{a}$ & $17.4 \mathrm{c}$ & $79.9 \mathrm{a}$ & $428.4 \mathrm{~b}$ & $51.4 \mathrm{a}$ \\
\hline BRSIPR Bel & $46.1 \mathrm{~b}$ & $1.10 \mathrm{c}$ & $10.20 \mathrm{a}$ & $22.09 \mathrm{~b}$ & $81.1 \mathrm{a}$ & $92.0 \mathrm{a}$ & $82.1 \mathrm{a}$ & $40.7 \mathrm{c}$ & $495.2 \mathrm{~b}$ & $26.0 \mathrm{a}$ & $88.6 \mathrm{a}$ & $398.8 \mathrm{c}$ & $52.4 \mathrm{a}$ \\
\hline Cupido & $46.7 \mathrm{~b}$ & $1.19 \mathrm{c}$ & $8.65 \mathrm{~b}$ & $18.50 \mathrm{~d}$ & $76.5 \mathrm{~b}$ & $90.8 \mathrm{a}$ & $79.3 \mathrm{a}$ & $37.3 \mathrm{~d}$ & $515.0 \mathrm{~b}$ & $23.1 \mathrm{~b}$ & $84.2 \mathrm{a}$ & $377.4 \mathrm{c}$ & $43.9 \mathrm{~b}$ \\
\hline Ágata & $41.7 \mathrm{c}$ & $0.97 \mathrm{~d}$ & $7.10 \mathrm{c}$ & $16.95 \mathrm{~d}$ & $79.4 \mathrm{~b}$ & $92.7 \mathrm{a}$ & $77.0 \mathrm{a}$ & $42.3 \mathrm{c}$ & $624.8 \mathrm{a}$ & $19.5 \mathrm{c}$ & $80.2 \mathrm{a}$ & $356.1 \mathrm{c}$ & $41.9 \mathrm{~b}$ \\
\hline Nicolet & $39.2 \mathrm{c}$ & $0.92 \mathrm{~d}$ & $7.84 \mathrm{c}$ & $20.03 \mathrm{c}$ & $80.6 \mathrm{a}$ & $89.0 \mathrm{~b}$ & $77.1 \mathrm{a}$ & $35.4 \mathrm{~d}$ & $462.1 \mathrm{~b}$ & $18.8 \mathrm{c}$ & $72.6 \mathrm{~b}$ & $487.7 \mathrm{a}$ & $47.6 \mathrm{~b}$ \\
\hline FL22 & 9 c & $1.41 \mathrm{~b}$ & $10.07 \mathrm{a}$ & $23.52 b$ & $79.6 \mathrm{~b}$ & $8 \mathrm{~b}$ & $71.1 \mathrm{~b}$ & $36.0 \mathrm{~d}$ & $447.6 \mathrm{~b}$ & $1 \mathrm{c}$ & $5.1 \mathrm{~b}$ & $440.9 \mathrm{~b}$ & $52.3 \mathrm{a}$ \\
\hline FL2027 & $50.8 \mathrm{a}$ & $1.24 \mathrm{c}$ & $10.51 \mathrm{a}$ & $20.68 c$ & $81.7 \mathrm{a}$ & $90.7 \mathrm{a}$ & $80.0 \mathrm{a}$ & $39.0 \mathrm{c}$ & $456.1 \mathrm{~b}$ & $22.3 \mathrm{~b}$ & $74.4 \mathrm{~b}$ & $394.8 \mathrm{c}$ & $47.1 \mathrm{~b}$ \\
\hline FL1867 & $41.9 \mathrm{c}$ & $1.68 \mathrm{a}$ & $10.25 \mathrm{a}$ & $24.63 b$ & $76.6 \mathrm{~b}$ & $87.3 \mathrm{~b}$ & $69.0 \mathrm{~b}$ & $41.3 \mathrm{c}$ & $528.8 \mathrm{a}$ & $20.5 c$ & $77.5 \mathrm{~b}$ & $469.8 \mathrm{a}$ & $56.4 \mathrm{a}$ \\
\hline FL2221 & $39.9 \mathrm{c}$ & $1.19 \mathrm{c}$ & $9.60 \mathrm{a}$ & $24.34 \mathrm{~b}$ & $84.2 \mathrm{a}$ & $91.1 \mathrm{a}$ & $\mathrm{a}$ & 4 & $561.2 \mathrm{a}$ & & & $435.5 b$ & $55.1 \mathrm{a}$ \\
\hline Atlantic & $1 \mathrm{c}$ & $1.31 \mathrm{~b}$ & $10.33 \mathrm{a}$ & $23.67 \mathrm{~b}$ & $80.6 \mathrm{a}$ & $90.4 \mathrm{a}$ & $77.7 \mathrm{a}$ & $48.2 \mathrm{~b}$ & $532.2 \mathrm{a}$ & $20.0 \mathrm{c}$ & $92.4 \mathrm{a}$ & $429.9 \mathrm{~b}$ & $44.8 \mathrm{~b}$ \\
\hline Acumulator & $35.1 \mathrm{~d}$ & $1.12 \mathrm{c}$ & $8.32 \mathrm{~b}$ & $23.66 \mathrm{~b}$ & $81.3 \mathrm{a}$ & $88.0 \mathrm{~b}$ & $78.1 \mathrm{a}$ & $49.3 \mathrm{~b}$ & $493.1 \mathrm{~b}$ & $23.2 \mathrm{~b}$ & $83.8 \mathrm{a}$ & $490.5 \mathrm{a}$ & $48.8 \mathrm{~b}$ \\
\hline Verdi & $31.8 \mathrm{e}$ & $1.12 \mathrm{c}$ & $8.66 \mathrm{~b}$ & $27.25 \mathrm{a}$ & $83.8 \mathrm{a}$ & $92.0 \mathrm{a}$ & $73.0 \mathrm{~b}$ & $54.2 \mathrm{a}$ & 593.9 a & $16.3 \mathrm{c}$ & $81.4 \mathrm{a}$ & $394.9 \mathrm{c}$ & $46.6 \mathrm{~b}$ \\
\hline Taurus & $30.8 \mathrm{e}$ & $0.90 \mathrm{~d}$ & $7.33 \mathrm{c}$ & $23.75 \mathrm{~b}$ & $82.5 \mathrm{a}$ & $90.4 \mathrm{a}$ & $75.5 \mathrm{a}$ & $44.3 \mathrm{c}$ & $576.9 \mathrm{a}$ & $17.6 \mathrm{c}$ & $77.6 \mathrm{~b}$ & $491.1 \mathrm{a}$ & $46.4 \mathrm{~b}$ \\
\hline $\mathrm{F}$ & $24.64^{* *}$ & $5.78^{* *}$ & $23.75^{* *}$ & $20.38^{* *}$ & $2.34^{*}$ & $2.88^{* *}$ & $4.22^{* *}$ & $11.25^{* *}$ & $12.61^{* *}$ & $7.48^{* *}$ & $3.48^{* *}$ & $4.58^{* *}$ & $5.25^{\text {** }}$ \\
\hline Mean & 40.8 & 1.17 & 9.01 & 22.23 & 80.5 & 90.2 & 76.2 & 42.8 & 525.5 & 20.9 & 79.3 & 430.5 & 48.8 \\
\hline $\mathrm{CV}(\%)$ & 6.3 & 16.7 & 6.2 & 4.0 & 4.5 & 2.6 & 5.6 & 9.0 & 14.4 & 13.2 & 10.9 & 10.9 & 8.8 \\
\hline
\end{tabular}

${ }^{1}$ Means followed for different letter in the column differs by grouping criteria of Scott-Knott at $5 \%$ probability. ** F significant at $1 \%$ probability. * F significant at $5 \%$ probability. ns - F no significant at $10 \%$ probability. 
The processes of cellular division and expansion are maintained for plants with higher nutrient use efficiency, even with low levels of nutrients in the tissues (KAVANOVA et al., 2006; AQUINO et al., 2015). Balemi and Schenk (2009) observed differences among genotypes regarding phosphorus use efficiency, so that those with greater use efficiency presented higher production of dry matter.

There was differences between all cultivars as regard $\mathrm{N}$ use efficiency in the shoot. Verdi cultivar produced on average 54.2 kilograms of dry matter for each $\mathrm{kg}$ of $\mathrm{N}$ absorbed, while Cupido, Nicolet and FL2215 produced 37.3, 35.4 and $36.0 \mathrm{~kg}$ of dry matter per $\mathrm{kg}$ of $\mathrm{N}$ absorbed, respectively. Lower use efficiency is due to greater absorption of these nutrients, because as the content of nutrient increase in the plant the coefficient of biological utilization decreases as a consequence of the increasing nutrient accumulation, proportionally, greater to the dry matter of the plant (AQUINO et al., 2015; DEZORDI et al., 2015).

Some cultivars presented low coefficient of biological utilization of $\mathrm{N}$, however high values of dry matter in the shoot, as observed for FL1867 and Atlantic cultivars. Fernandes and Soratto (2013) verified that Mondial cultivar, despite having lower use efficiency, produced higher quantities of dry matter, and according to the authors, it suggest that high production of dry matter is due to higher absorption of some nutrients, and not due to greater use efficiency in the metabolism, consequently, on the production of dry matter.

There was difference among cultivars for coefficient of biological utilization of $\mathrm{P}$ and $\mathrm{K}$ in the shoot (Table 1). Different coefficient of biological utilization of these nutrients may be related to the capacity to export photoassimilates from the shoot to the tubers. The cultivars more efficient to export photoassimilates, with high productivities, also export more quantities of $\mathrm{P}$ and $\mathrm{K}$ to the tubers. It happens because these nutrients are more accumulated in the tubers (FERNANDES; SORATTO and SILVA, 2011). With high exportation, the ratio between dry matter and nutrients in the shoot increase, which means, higher coefficient of biological utilization. There was difference among cultivars regarding the coefficient of biological utilization of N, P and $\mathrm{K}$ in the tubers (Table 1). Asterix, BRSIPR Bel, Cupido, Ágata, Atlantic, Acumulator and Verdi cultivars presented higher coefficient of biological utilization of $\mathrm{N}$ for the tubers productivity. Higher coefficient of biological utilization for the tubers were observed in Nicolet, FL1867, Acumulator and Taurus cultivars for $\mathrm{P}$.

Fernandes and Soratto (2012) evaluating the influence of P accumulation and dry matter partition on $\mathrm{P}$ use efficiency and the nutritional status of Ágata cultivar, grown in nutrient solution, observed that increasing availability of $\mathrm{P}$ also increased the $\mathrm{P}$ content, the accumulation and absorption efficiency, but decreased the use efficiency, which agree with this study, high absorption ratio did not imply in greater yield potential for any of the cultivars, such as Taurus cultivars, that even with high coefficient of biological utilization of $\mathrm{P}$, had the lowest productivity among cultivars.

Cultura Agronômica, Ilha Solteira, v.27, n.2, p.251-261, 2018 

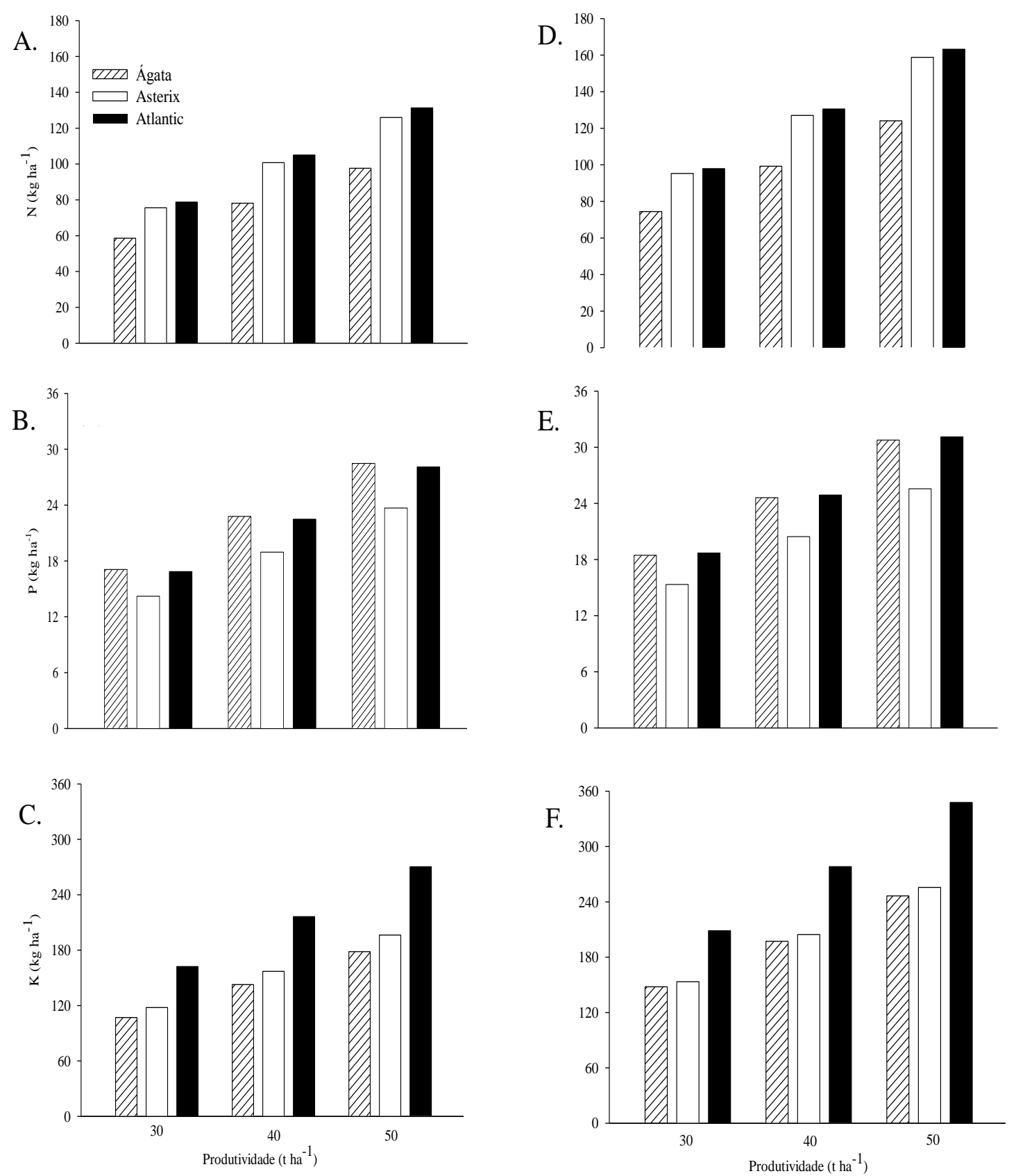

Figure 1. Estimation of export (A, B, C) and extraction (D, E, F) of N, P and $\mathrm{K}$ as function of productivity for the potato cultivars Ágata, Asterix and Atlantic.

Asterix, BRSIPR Bel, FL2215, FL1867 and FL2221 cultivars were more efficient in $\mathrm{K}$ use given higher values of the coefficient of biological utilization for the tubers production (Table 1). Higher coefficient of biological utilization of this nutrient in a cultivar is important to the efficient management of potassic fertilization, once $\mathrm{K}$ is the more extracted and exported nutrient for potato crop (FERNANDES; SORATTO and SILVA, 2011; FERNANDES and SORATTO, 2013). Higher coefficient of biological utilization of $\mathrm{K}$, special in the tubers (part of the plant that accumulates more quantity of the nutrient), 
may result in less necessity of $\mathrm{K}$ fertilization, compared to other cultivars with lower coefficient of biological utilization.

The knowledge about coefficient of biological utilization and harvest index of dry matter and nutrients allow the estimation of nutrient accumulation as function of the productivity. This estimation vary not only with the productivity, but also with the cultivars, due to differences of its coefficient of biological utilization and harvest index, as exemplified for Ágata, Asterix and Atlantic cultivars in the Figure 1 (A, B, C, D, E, F).

Atlantic cultivar presented higher estimation of the extraction and exportation of $\mathrm{N}, \mathrm{P}$ and $\mathrm{K}$. Extraction and exportation of $\mathrm{N}$ of Asterix cultivar were similar to Atlantic cultivar. Ágata cultivar is similar to Atlantic cultivar as for the extraction and exportation of $\mathrm{P}$. Higher extraction and exportation of $\mathrm{N}, \mathrm{P}$ and $\mathrm{K}$ for Atlantic cultivar may be related to higher content of dry matter in the tubers and high harvest index of these nutrients. Higher extraction and exportation of $\mathrm{P}$ for Ágata cultivar can be related to lower coefficient of biological utilization of $\mathrm{P}$, in special in the tubers, part of the plant with greater accumulation of the nutrient.

Future studies, which determine the recovery efficiency of $\mathrm{N}, \mathrm{P}$ and $\mathrm{K}$ by potato cultivars, will allow better estimation of rates to be applied via fertilizers of these nutrients. The fertilizers rates should consider the extraction and capacity of the plant recover the nutrients from the soil.

\section{CONCLUSION}

FL2027 cultivar was more productive.

The coefficient of biological utilizations for $\mathrm{N}, \mathrm{P}$ and $\mathrm{K}$ is different among potato cultivars.

In general, Atlantic cultivar presented greater extraction and exportation of $\mathrm{N}, \mathrm{P}$ and $\mathrm{K}$ than Ágata and Asterix cultivars.

\section{REFERENCES}

AQUINO, R. F. B. A.; ASSUNÇÃO, N. S.; AQUINO, L. A.; AQUINO, P. M.; OLIVEIRA, G. A. CARVALHO, A. M. X. Nutrient demand by the carrot crop is influenced by the cultivar. Revista Brasileira de Ciência do Solo, Viçosa, v. 39, n. 2, p.1-12, 2015.

BALEMI, T.; SCHENK, M. K. Genotypic variation of potato for phosphorus efficiency and quantification of phosphorus uptake with respect to root characteristics. Journal of Plant Nutrition and Soil Science, Temuco, v. 172, n. 5, p.669-677, 2009.

BREGAGNOLI, M.; BREGAGNOLI, F. C. R.; MINAMI, K.; GRATIERI, L. A. MINCHILLO, M. Análise bromatológica de sete cultivares de batata (Solanum tuberosum

Cultura Agronômica, Ilha Solteira, v.27, n.2, p.251-261, 2018 
L.) cultivadas na safra de verão no Sul de Minas Gerais. Horticultura Brasileira, Vitoria da Conquista, v. 21, n. 1, p.387-387, 2003.

CARdoso, A. D.; AlvarengA, M. A. R.; MELO, T. L.; VIANA, A. E. S. Produtividade e qualidade de tubérculos de batata em função de doses e parcelamentos de nitrogênio e potássio. Ciência e Agrotecnologia, Lavras, v. 31, n. 6, p.1729-1736, 2007.

CECÍLIO FILHO, A. B.; PEIXOTO, F. C. Acúmulo e exportação de nutrientes em cenoura 'Forto'. Revista Caatinga, Mossoró, v. 26, n. 1, p.64-70, 2013.

DEZORDI, L. R.; AQUINO L. A.; NOVAIS, R. F.; AQUINO, P. M.; SANTOS, L. P. D. Nutrient recommendation model for carrot crop - Ferticalc Carrot. Revista Brasileira de Ciência do Solo, Viçosa, v. 39, n. 6, p.1714-1722, 2015.

FOOD AND AGRICULTURE ORGANIZATION - FAO. Preliminary 2009 data now available for selected countries and products. Available at: 〈http://fao.org>. Accessed on: 08 Apr. 2017.

FERNANDES, A. M.; SORATTO, R. P.; SILVA, B. L. Extração e exportação de nutrientes em cultivares de batata: I - macronutrientes. Revista Brasileira de Ciência do Solo, Viçosa, v. 35, n. 6, p.2039-2056, 2011.

FERNANDES, A. M.; SORATTO, R. P.; SILVA, B. L.; SOUZA-SCHLICK, G. D. Crescimento, acúmulo e distribuição de matéria seca em cultivares de batata na safra de inverno. Pesquisa Agropecuária Brasileira, Brasília, v. 45, n. 8, p.826-835, 2010.

FERNANDES, A. M.; SORATTO, R. P. Nutrition, dry matter accumulation and partitioning and phosphorus use efficiency of potato grown at different phosphorus levels in nutrient solution. Revista Brasileira de Ciência do Solo, Viçosa, v. 36, n. 5, p.1528-1537, 2012.

FERNANDES, A. M.; SORATTO, R. P. Eficiência de utilização de nutrientes por cultivares de batata. Bioscience Journal, Uberlândia, v. 29, n. 1, p.91-100, 2013.

KAVANOVA, M.; LATTANZI, F. A.; GRIMOLDI, A. A.; SCHNYDER, H. Phosphorus deficiency decreases cell division and elongation in grass leaves. Plant Physiology, Glasgow, v. 141, n. 2, p.766-775, 2006.

KAWAKAMI, J. Redução da adubação, doses e parcelamento de nitrogênio no crescimento e produtividade de batata. Horticultura Brasileira, Vitoria da Conquista, v. 33, n. 2, p.168$173,2015$.

LULAI, E. C.; ORR, P. H. Influence of potato specific gravity on yield and oil content of chips. American Journal of Potato Research, Ann Arbor, v. 56, n. 8, p.379-390, 1979.

LUZ, J. M. Q.; QUEIROZ, A. A.; OLIVEIRA, R. C. Teor crítico foliar de nitrogênio na batata 'Asterix' em função de doses de nitrogênio. Horticultura Brasileira, Vitoria da Conquista, v. 32, n. 2, p.225-229, 2014.

Cultura Agronômica, Ilha Solteira, v.27, n.2, p.251-261, 2018 
MAlavoltA, E.; VITTI, G. C.; OLIVEIRA, S. A. Avaliação do estado nutricional das plantas. Princípios e aplicações. 1. ed. Piracicaba: Associação Brasileira para Pesquisa da Potassa e do Fosfato, 1997. 319 p.

MALLMANN, N.; LUCCHESI, L. A. C.; DESCHAMPS, C. Influência da adubação com NPK na produção comercial e rentabilidade da batata na região Centro-Oeste do Paraná. Revista Brasileira de Tecnologia Aplicada nas Ciências Agrárias, Guarapuava, v. 4, n. 3, p.67-82, 2012.

PEREIRA, A. S.; SILVA, R. S.; BENDER, C. I.; FERRI, M. L.; VENDRUSCOLO, J. L. Genótipos de batata com baixo teor de açúcares redutores. Horticultura Brasileira, Vitoria da Conquista, v. 25, n. 2, p.220-223, 2007.

QUEIROZ, L. R. M.; KAWAKAMI, J.; MULLE, M. L.; OLIARI, I. C. R.; UMBURANAS, R. C.; ESCHEMBACK, V. Adubação NPK e tamanho da batata-semente no crescimento, produtividade e rentabilidade de plantas de batata. Horticultura Brasileira, Vitoria da Conquista, v. 31, n. 1, p.119-127, 2013.

SILVA, F. L.; PINTO, C. A. B. P.; ALVES, J. D.; BENITES, F. R. G.; ANDRADE, C. M.; RODRIGUES, G. B.; LEPRE, A. L.; BHERING, L. P. Caracterização morfofisiológica de clones precoces e tardios de batata visando à adaptação a condições tropicais. Bragantia, Campinas, v. 68, n. 2, p.295-302, 2009.

TEKALIGN, T.; HAMMES, P. S. Growth and productivity of potato as influenced by cultivar and reproductive growth. I. Stomatal conductance, rate of transpiration, net photosynthesis, and dry matter production and allocation. Scientia Horticulturae, Amsterdam, v. 105, n. 1, p.13-27, 2005. 